\title{
Is there any Synchronization between Blood in Urine and Dandruff?
}

\author{
Muhammad Imran Qadir and Usama Razzaq* \\ Institute of Molecular Biology and Biotechnology, Bahauddin Zakariya University, Multan, Pakistan
}

*Corresponding author: Institute of Molecular Biology and Biotechnology, Bahauddin Zakariya University, Multan, Pakistan

\begin{tabular}{|c|c|}
\hline ARTICLE INFO & ABSTRACT \\
\hline Received: 幽 June 06, 2019 & \multirow{3}{*}{$\begin{array}{l}\text { The utmost intention of this article was to assess if there is a connection between } \\
\text { blood in urine and dandruff. Presence of } 5 \text { or more red blood cells in urine is known as } \\
\text { hematuria. Macroscopic or gross hematuria has visibility of RBCs in urine seen through } \\
\text { naked eye while microscopic hematuria has } 3 \text { or more RBCs in urine can see under mi- } \\
\text { croscopic vision. Dandruff is a epidermal scaling of the scalp in which extra skin cells } \\
\text { initiate to die and shed like flakes. It was concluded that there is no relation of hematuria } \\
\text { and dandruff. }\end{array}$} \\
\hline Published: 慧 June 12, 2019 & \\
\hline $\begin{array}{l}\text { Citation: Muhammad Imran Qadir, Usa- } \\
\text { ma Razzaq. Is there any Synchronization } \\
\text { between Blood in Urine and Dandruff?. }\end{array}$ & \\
\hline $\begin{array}{l}\text { Biomed J Sci \& Tech Res 18(5)-2019. } \\
\text { BJSTR. MS.ID.003207. }\end{array}$ & $\begin{array}{l}\text { Keywords: Hematuria; Red blood cells; Dandruff; Anti-dandruff shampoos; Home rem- } \\
\text { edies }\end{array}$ \\
\hline
\end{tabular}

\section{Introduction}

Presence of 5 or more red blood cells in urine is known as hematuria. The hematuria has two types based on the visibility of RBCs in urine. Macroscopic or gross hematuria has visibility of RBCs in urine seen through naked eye while microscopic hematuria has 3 or more RBCs in urine can see under microscopic vision. Normal urine colour is amber yellow but hematuria is red in colour. To distinguish components in hematuria, blood is centrifuged, two layers appear. Clear supernatant is myoglobinuria while haemoglobinuria is serum-pink supernatant. Causes of hematuria may be due to urinary tract infection, kidney stones, kidney infections, enlargement of prostate gland, kidney diseases, genetic disorders, medicinal usage and kidney injury. Infection of urinary tract may be due to entry of bacteria in body via urethra and begun to proliferate within bladder. Symptoms may include frequent urination along with pain and burning. Kidney stones develop due to accumulation of minerals from concentrated urine in kidney and form crystal like appearance and afterwards changes into hard stone that block urine flow. Enlargement of prostate gland may occur when a man approaches to a middle age. This is natural, enlarged prostate then block urine and produces difficulty in urinating. Kidney diseases include kidney stone, malfunctioning of nephron, glomerulus, disorder may occur in capillaries or blood vessels. Genetic disorder may be sickle cell anemia which is a genetic defect of hemoglobin. Medicinal usage means use of drugs against cancer such as cyclophosphamide and penicillin can cause hematuria.

While kidney injury means damage to kidney due to some accident may be a cause of hematuria. For hematuria, antibiotics can be used to treat infection of urinary bladder, to break stones shock wave therapy is applied and medicine also available to shrink the enlarged size of prostate gland. Dandruff is a epidermal scaling of the scalp in which extra skin cells initiate to die and shed like flakes. Dandruff's study falls under the subject of dermatology. Almost half of the people worldwide are affected by it. In dandruff, scalp may be oily or dry. In dry scalp, skin cells begun to dehydrate while in oily scalp there is too much oil on the scalp means more sebum production due to over-activity of sebaceous glands. Signs of dandruff include itchy, inflammation, redness, scaling, patches, dryness, oily scalp and irritation. Cradle cap is a type of dandruff occurring in babies of two months and remains for a few weeks or months. Signs include crusty and scaling of scalp. Seborrhoeic dermatitis is a type of dandruff affecting areas of body like the scalp, face, ears and armpits. Signs include itchiness and scaling. Dandruff is caused by a fungus malassezia which evolves on scalp, trigger the growth of skin cells, extra skin cells perish and shed as white dots. Other causes may include factors like environmental, nutritional, hormonal problems and use of hair-style products. Environmental problems include dust, pollution and changes in weather pattern. 
Nutritional problems include eating food not containing essential nutrients like zinc and vitamins. Hormonal problems include increase in androgens levels which relates with taking some stress and over-secretion of sebum. Hair-style products involve habitual of hair- gels, shampoos, hair soaps and hair spray.

Treatment includes the use of shampoos and home remedies. Anti-dandruff shampoos having selenium sulphide, zinc pyrithione, ketoconazol and tea tree oil as a special formulating agent are effective in curing dandruff. Selenium sulphide is an integral element in treating dandruff as it reduces oil production in the scalp, zinc pyrithione is efficient in reducing fungus's growth, Ketoconazol has anti-fungal characteristics and tea tree oil is useful in curing dandruff symptoms because of its anti-fungal, anti-septic and antibiotic properties. Home remedies are also productive in the management of dandruff symptoms. Olive oil usage reduces desiccation of scalp and has anti-viral and anti-inflammatory properties to cure irritation and infection. Apply eggs on hair provide essential protein to hairs effective in reducing hair loss and improves toughness of hairs. Fenugreek seeds have high contents of protein useful in prevention of hair loss and also moisturizes the scalp. The ultimate target of this article was to assess if there is a connection between blood in urine and dandruff.

\section{Materials and Methods}

For the analysis of blood in urine, fully immersed the test strip into the container containing the urine of the patient. To prevent cross contamination, test strip should remain horizontal. The test strip has a indicator chemical which shows a characteristic colour after reacting with compound in the urine. Presence of blood in urine will be confirmed when colour of chromogen indicator changes when it oxidized by the reaction of hemoglobin with peroxidase substrate. The colour then compares with the urine dipsticks.

\section{Project Designing}

To check if there is any relation exists between blood in urine and dandruff, data of 100 students were taken who have undergone their urine test. They answered the survey question in accordance of their urine reports of having or not having blood in their urine. These students belong to Bahauddin Zakariya university, Multan, Pakistan

\section{Statistical Analysis}

Statistical analysis was carrying out on Microsoft Excel.

Results: (Tables 1 \& 2)

Table 1: Percentage of association between hematuria and dandruff symptoms.

\begin{tabular}{|c|c|c|c|c|c|}
\hline Gender & Present (Hemolytic) & Absent (Hemolytic) & Present (Non-Hemolytic) & Absent (Non-Hemolytic) & Percentage \\
\hline Male & $12 \%$ & $25 \%$ & $0 \%$ & $5 \%$ & $42 \%$ \\
\hline Female & $2 \%$ & $30 \%$ & $4 \%$ & $20 \%$ & $58 \%$ \\
\hline
\end{tabular}

Table 2: Relation between hematuria and not having dandruff symptoms.

\begin{tabular}{|c|c|c|c|c|c|}
\hline Gender & Present (Hemolytic) & Absent (Hemolytic) & Present (Non-Hemolytic) & Absent (Non-Hemolytic) & Percentage \\
\hline Male & $2 \%$ & $12 \%$ & $10 \%$ & $20 \%$ & $44 \%$ \\
\hline Female & $1 \%$ & $21 \%$ & $2 \%$ & $32 \%$ & $56 \%$ \\
\hline
\end{tabular}

\section{Discussion}

According to table No. 01, about $25 \%$ male with absence of hemolytic urine have symptoms of dandruff and about $30 \%$ female with absence of hemolytic urine also have symptoms of dandruff. But in table No. 02, about $20 \%$ male with absence of non-hemolytic urine also don't have dandruff symptoms and about $32 \%$ female with absence of no-hemolytic urine also don't infected by dandruff.

\section{Conclusion}

It was concluded that there is no relation of hematuria and dandruff.

\section{References}

1. Qadir MI, Malik SA (2010) Comparison of alterations in red blood cell count and alterations in hemoglobin concentration in patients suffering from rectal carcinoma undergoing 5-fluorouracil and folic acid therapy. Pharmacology online Nl 3: 240-243.

2. Qadir MI, Noor A (2018) Anemias. Rare \& Uncommon Diseases. In Qadir MI, Noor A(Eds.), Cambridge Scholars Publishing, Newcastle, England.
3. Qadir MI, Javid A (2018) Awareness about Crohn's Disease in biotechnology students. GloAdv Res J Med Medical Sci 7(3): 062-064.

4. Qadir MI, Saleem A (2018) Awareness about ischemic heart disease in university biotechnology students. GloAdv Res J Med Medical Sci 7(3): 059-061.

5. Qadir MI, Ishfaq S (2018) Awareness about hypertension in biology students. Int J Mod Pharma Res 7(2): 08-10.

6. Qadir MI, Mehwish (2018) Awareness about psoriasis disease. Int J Mod Pharma Res 7(2): 17-18.

7. Qadir MI, Shahzad R (2018) Awareness about obesity in postgraduate students of biotechnology. Int J Mod Pharma Res 7(2): 14-16.

8. Qadir MI, Rizvi M (2018) Awareness about thalassemia in post graduate students. MOJ Lymphology \& Phlebology 2(1): 14-16.

9. Qadir MI, Ghalia BA (2018) Awareness survey about colorectal cancer in students of M. Phil Biotechnology at Bahauddin Zakariya University, Multan, Pakistan. Nov Appro in Can Study, 1(3): NACS.000514.2018.

10. Qadir MI, Saba G (2018) Awareness about intestinal cancer in university student. Nov Appro in Can Study 1(3): NACS.000515.2018. 


\section{ISSN: 2574-1241}

DOI: 10.26717/BJSTR.2019.18.003207

Usama Razzaq. Biomed J Sci \& Tech Res

(C) (P) This work is licensed under Creative

Submission Link: https://biomedres.us/submit-manuscript.php

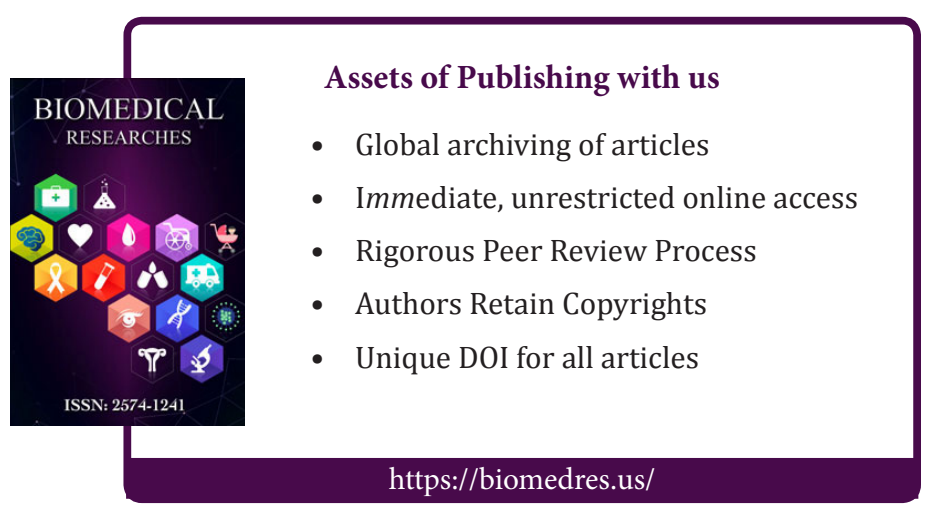

